\title{
MISTERIUM PASCHALNE CHRYSTUSA CENTRALNYM WYDARZENIEM ŻYCIA KOŚCIOKA.
}

Chrystus Pan dokonał dzieła odkupienia ludzi i doskonałego uwielbienia Boga przez paschalne misterium swojej błogosławionej Męki, Zmartwychwstania i chwalebnego Wniebowstąpienia (por. KL 5).

Sobór Watykański II pouczył, że to właśnie w liturgii, szczególnie przez Ofiarę Eucharystyczną i sakramenty, dokonuje się „dzieło naszego odkupienia" (KL 2.6): uświęcenie człowieka w Chrystusie i uwielbienie Boga, „które jest celem wszystkich innych dzieł Kościoła" (KL 10). Stąd też fundamentalnym celem reformy liturgicznej stał się „wysiłek duszpasterskiej działalności Kościoła, skupionej wokól liturgii”, zdążający do wyrażenia i zrealizowania w życiu wiernych, uobecnianego w liturgii misterium paschalnego. Chodzi o to, aby wierni włączeni w misterium Śmierci i Zmartwychwstania Chrystusa, obumarli dla grzechu i upodobnieni do Chrystusa ,już nie dla siebie żyli, lecz dla Tego, który za nich umarł i zmartwychwstał” $(2 \text { Kor } 5,15)^{1}$. „Ponieważ śmierć Chrystusa na krzyżu i Jego zmartwychwstanie stanowią treść codziennego życia Kościoła i zapowiedź wiecznej Paschy, pierwszym zadaniem liturgii jest niestrudzone wprowadzanie nas na otwartą przez Chrystusa paschalna drogę, na której człowiek godzi się umrzeć, aby mieć życie wieczne"2. To dzieło „dokonuje się przez wiarę i sakramenty wiary czyli przede wszystkim przez chrzest (por. KL 6) i Najświętsze Misterium Eucharystii (por. KL 47), wokół którego skupiają się pozostałe sakramenty i sakramentalia (por. KL 61) oraz "krąg tych obrzędów w których rozwija się paschalne Misterium Chrystusa w Kościele w ciągu roku (por. KL 102-107)"33. Takie rozumienie prawdy, wiary sprawiło, że Kościół od czasu, kiedy w dzień Zesłania Ducha Świętego ukazał się światu, „nie zaprzestawał zbierać się na odprawianie

${ }^{1}$ Święta Kongregacja Obrzędów (ŚKO), Instrukcja o należytym wykonywaniu Konstytucji o świętej liturgii (26. 09. 1964), n. 5.

${ }^{2} \mathrm{~J}$ a n $\mathrm{P}$ a w e $\nmid \mathrm{I}$ I, List Apostolski w dwudziesta piata rocznice ogloszenia Konstytucji soborowej „Sacrosanctum Concilium” o świętej liturgii (04. 12. 1988), n. 6.

${ }^{3}$ ŚKO, Instrukcja... dz. cyt., n. 6. 
paschalnego misterium... sprawując Eucharystię, w której uobecnia się zwycięstwo i triumf Jego śmierci" (KL 6). Eucharystia jako ośrodek całego życia chrześcijańskiego tak Kościoła powszechnego jak i lokalnego, w sposób szczególny gromadzi cały Lud Boży i sprawia, iż wierni, swoim życiem, wyrażają i ujawniają innym „misterium Chrystusa i rzeczywistą naturę prawdziwego Kościoła” (KL 2).

Sobór Watykański II ukazuje istotę wspólnoty Kościoła sprawującego liturgię, gdy mówi, że „czynności liturgiczne nie są czynnościami prywatnymi, lecz kultem Kościoła, będącego „sakramentem jedności”, a Kościół to lud święty, zjednoczony i zorganizowany pod zwierzchnictwem biskupów. Dlatego czynności liturgiczne należą do całego Ciała Kościoła, uwidoczniają je i na nie oddziałują" (KL 26). Kościół ukazuje się światu przede wszystkim w pełnym i czynnym uczestnictwie całego Ludu Bożego w Liturgii, a zwłaszcza „w tej samej Eucharystii, w jednej modlitwie, przy jednym ołtarzu pod przewodnictwem biskupa, otoczonego kapłanami i sługami ołtarza" (KL 41).

Chodzi tu o „dynamikę zbawczego działania, przez które Zbawiciel realizuje nasze przejście ze śmierci do życia, z niewoli do wolności, od grzechu do świętości”^. Kościół bowiem jest „ludzki i jednocześnie boski, widzialny i wyposażony w dobra niewidzialne, żarliwy w działaniu i oddany kontemplacji, obecny w świecie, a jednak pielgrzymujący” (KL 2). „Przez Eucharystię Kościół nieustannie żyje i wzrasta” (EM 7); „przez nią dokonywa się uświęcenie człowieka w Chrystusie i uwielbienie Boga, które jest celem wszystkich innych dzieł Kościoła" (KL 10).

Zbawcze działanie Chrystusa „z Jego szczytowym dopełnieniem, dokonanym raz na zawsze w misterium paschalnym, staje sie przez liturgię fundamentalną wartością chrześcijańskiego życia". Eklezjalny wymiar misterium paschalnego, jak ukazują to euchologijne teksty nowego Mszału, to nie tylko obecność Pana, ale „transpozycja Jego misterium paschalnego na wspólnotę Kościoła, polegająca na przemianie całego naszego bytu i życia na modłę sposobu bytowania Chrystusa"6. Dlatego Kościół nieustannie aktualizuje i uobecnia misterium paschalne w liturgii, zwłaszcza eucharystycznej, w której „Bóg otrzymuje doskonałą chwałę a ludzie uświęcenie”, Chrystus zaś "zawsze przyłącza do siebie Kościół, swoją Oblubienicę umilowaną" (KL 7).

${ }^{4}$ W. Ś w i e r z a w s k i, Dynamiczna „Pamiatka Pana”. Eucharystyczna anamneza Misterium Paschalnego i jego egzystencjalna dynamika, Kraków 1980, 67.

${ }^{5}$ Tamże.

6 Tamże, 68. 


\section{KOŚCIÓ£ AKTUALIZUJĄCY MISTERIUM PASCHALNE}

Odpowiedzią na uprzedzającą miłość Boga objawioną w obecności i działaniu Chrystusa Pana, jest obecność i działanie Kościoła, który nie zaprzestaje zbierać się na odprawianie paschalnego misterium (por. KL 6), sprawując Eucharystię, w której „dokonuje się dzieło naszego Odkupienia” (KL 2); przez którą „Kościół nieustannie żyje i wzrasta" (EM 7).

Euchologia okresu wielkanocnego Mszału Pawła VI przedstawiając tę obecność i działanie Kościoła, opisuje, wyrażeniami biblijnymi, społeczność nowego Ludu Bożego, używając charakterystycznych określeń łacińskich: „ecclesia, familia, famuli, fideles, plebs, populus". Kontekst, w którym są umieszczone powyższe wyrażenia pozwala na odczytanie całej głębi teologicznej zawartej w modlitwach nowej księgi ołtarza, a dotyczącej Kościoła.

\subsection{Ecclesia - Kościót}

Teksty modlitw używają przede wszystkim słowa „ecclesia” na określenie nowego Ludu Bożego, Kościoła: „Jednorodzony Syn... pozostawił Kościołowi nową wiekuistą Ofiarę i Ucztę swojej miłości”"; „wzbudź w Twoim Kościele ducha dziecięctwa”; „Boże... składamy Tobie Ofiarę, przez którą Kościół odradza się", „Boże, Ty przez wielkanocne Sakramenty udzieliłeś Twojemu Kościołowi nowego życia”10; „Boże, Ty przez chrzest nieustannie pomnażasz liczbę dzieci swojego Kościoła”"11; „Boże, przyjmij świąteczne dary Kościoła”12; „Boże... przez udział w Eucharystii umocnij naszą ufność, że cały Kościół zjednoczy się w chwale z Chrystusem”"13; „niech błogosławieństwo Ducha Swiętego zstąpi na te dary i wzbudzi w Twoim Kościele... miłość"14; „Boże, Ty przez misterium dnia dzisiejszego

${ }^{7}$ Kolekta (=K) Wielkiego Czwartku. Msza Wieczerzy Pańskiej (Mszat Rzymski dla diecezji polskich, Poznań 1986 s. 127(=MRP 127).

${ }^{8}$ K Wigilii Paschalnej (MRP 171).

${ }^{9}$ Modlitwa nad darami (=Mnd) Niedzieli Wielkanocnej (=Niedz. Wielk.) (RP 184).

${ }^{10}$ Modlitwa po Komunii (=MpK) Niedz. Wielk. (MRP 185).

${ }^{11} \mathrm{~K}$ poniedziałku (=pon.) w Oktawie Wielk. (MRP 186).

12 Mnd 3 Niedz. Wielk. (MRP 2000). Tekst tej modlitwy występuje w nowym Mszale jeszcze pięciokrotnie; zob. MRP 194.203.209.217.223.

${ }_{13}^{13}$ MpK 7 Niedz. Wielk. (MRP 231).

${ }^{14}$ Mnd Niedz. Zesłania (=Zesł.) Ducha Św. (Wieczorna Msza Wigilijna) (MRP 238). 
uświęcasz swój Kościół ogarniający wszystkie ludy i narody"15; „Boże, Ty udzielasz swojemu Kościołowi nadprzyrodzonych darów"16; „Miłosierny Boże, spraw, aby Twój Kościół zgromadzony przez Ducha Świętego służył Ci z całym oddaniem"17.

Teksty euchologijne w sposób bardzo wyraźny charakteryzują nam Kościół, któremu Jednorodzony Syn pozostawił nową wiekuistą Ofiarę i Ucztę swojej miłości. Kościół to wspólnota ogarniająca wszystkie ludy i narody; przez chrzest powiększa liczbę swoich dzieci; w duchu dziecięctwa (przybrania) służy Bogu z całkowitym oddaniem. Jest to spoleczność wiernych, którzy otrzymują, przez wielkanocne sakramenty, nowe życie; poprzez udział w Eucharystii odradzają się, karmią się, żyją przykazaniem miłości; bogaci w nadprzyrodzone dary umacniają swą ufność na zjednoczenie w chwale z Chrystusem.

Łatwo zauważyć z powyższego, iż modlitwy Mszału (lex orandi) dobrze wyrażają wiarę (lex credendi) Kościoła, formułowaną m.in. w nauczaniu Vaticanum II: „Kościół ujawnia się przede wszystkim w pełnym i czynnym uczestnictwie całego Ludu Bożego w tych samych obchodach liturgicznych, zwlaszcza w tej samej Eucharystii" (KL 41). Chrystus Pan ustanowił Eucharystię, aby „umiłowanej Oblubienicy Kościołowi powierzyć pamiątkę swej Męki i Zmartwychwstania: sakrament miłosierdzia, znak jedności, węzeł miłości, ucztę paschalną" (KL 47). Sobór Watykański II podkreślając niejednokrotnie znaczenie misterium paschalnego w życiu chrześcijan poucza, że sakramenty oraz „wszystkie kościelne posługi i dzieła apostolstwa, wiążą się ze świętą Eucharystią i do niej zmierzają. W Najświętszej bowiem Eucharystii zawiera się całe duchowe dobro Kościoła, a mianowicie sam Chrystus, nasza Pascha i chleb żywy, który przez Ciało swoje ożywione i ożywiające Duchem Świętym daje życie ludziom, zapraszając ich i doprowadzając w ten sposób do ofiarowania razem z Nim samych siebie, swojej pracy i wszystkich rzeczy stworzonych" (DK 5). Sprawowanie Eucharystii, nowej Paschy, stanowi element jednoczący z chrześcijanami Wschodu. Obrzęd eucharystyczny jest dla nich źródłem życia Kościoła i zadatkiem przyszłej chwały; „przez niego wierni złączeni z biskupem, mający dostęp do Boga Ojca przez Syna, Słowo Wcielone, umęczone i uwielbione, oraz w szczodrobliwości Ducha Świętego dostępują zjednoczenia z Przenajświętszą Trójcą, stawszy się «uczestnikami Bożej natury» (2 P 1,4). Dlatego przez. sprawowanie Eucharystii Pańskiej w tych poszczególnych Kościołach buduje się i rozrasta Kościół Boży" (DE 15).

${ }^{15}$ K Niedz. Zesł. Ducha Św. (Msza w dzień) (MRP 239).

${ }^{16}$ MpK Niedz. Zesł. Ducha Św. (Msza w dzień) (MRP 240).

${ }^{17} \mathrm{~K}$ środy (=śr.) 7 tygodnia (=tyg.) wielk. (MRP 234). 


\subsection{Familia - Rodzina}

Zgromadzenie liturgiczne, które składa eucharystyczną Ofiarę i uczestniczy w misterium paschalnym, jest nazywane także „rodziną" - „familia”: „Boże, przyjmij łaskawie dary Twojej rodziny”" ; „Wysłuchaj nas, wszechmogący Boże i przygotuj do wiecznego szczęścia serca Twojej rodziny"19; "Wszechmogący Boże, przybądź z pomocą Twojej rodzinie"20?.

Kościół jest zatem „rodziną”. Dokumenty ostatniego Soboru używają tego wyrażenia na określenie Kościoła jako „rodziny synów Bożych w Chrystusie”, która „dopełnia i umacnia jedność rodziny ludzkiej” (KDK 42). Kościół nazywany jest „budowlą” Bożą (1 Kor 3, 9), która otrzymuje także nazwę: „dom Boga” (1 Tm 3, 15), w którym mieszka Jego rodzina (por. KK 6). Szafarze z upoważnienia Chrystusa nauczają, uświęcają i kierują „rodziną Bożą” (por. KK 32); „Albowiem wszyscy, którzy jesteśmy synami Bożymi i stanowimy jedną rodzinę w Chrystusie (por. Hbr 3,6), gdy łączymy się ze sobą we wzajemnej miłości i w jednej chwale Trójcy Przenajświętszej, odpowiadamy najgłębszemu powołaniu Kościoła i uczestniczymy w przedsmaku liturgii doskonałej chwały" (KK 51). Prezbiterzy, wypełniając urząd Chrystusa Głowy i Pasterza "gromadzą w imieniu biskupa rodzinę Bożą" (DK 6). Kościół, "sól ziemi i światło świata” (por. Mt 5, 13n), obecnie, kiedy nastają nowe warunki życia ludzkiego, jest powołany, „aby wszystko doznało naprawy w Chrystusie i aby w Nim ludzie tworzyli jedną rodzinę i jeden lud Boży" (DM 1). Sobór przypomina, iż Kościół nie zapomina o tym, że Jezus Chrystus sam „przyjmując ludzką naturę, związał ze sobą całą ludzkość pewną nadprzyrodzoną solidarnością w jedną rodzinę, a jako znak rozpoznawczy swych uczniów ustanowił miłość" (DA 8).

Bardzo wymownie, w kontekście współczesnego świata i jego problemów oraz na tle odnowionego języka Mszału rzymskiego (co świadczy nie mniej o dostrzeganiu aktualnych problemów), jawi się

${ }^{18}$ Mnd wtorku (=wt.) w Oktawie Wielk. (MRP 187). Lacińskie wyrażenie: „oblationes familiae tuae", polski Mszał tłumaczy „dary swoich wiernych”, pomijając niestety aspekt „rodzinny” w określeniu Kościoła, występujący jeszcze pięciokrotnie w okresie wielkanocnym (!): MRP 198.207.213.221.228.

${ }_{19} \mathrm{MpK}$ wt. w Oktawie Wielk. (MRP 187). Wyrażenie z Mszału rzymskiego: „familiae tuae corda" MRP oddaje jako: „serca Twoich wiernych”, znowu pomijając aspekt „rodzinny” (!).

${ }^{20} \mathrm{~K}$ śr. 3 tyg. wielk. (MRP 204). Typiczne wydanie Mszału używa

określenia: „Adesto ...Domine, familiae tuae”; Mszał w polskim wydaniu ma: „Wszechmogący Boże, przybądź z pomocą Twoim przybranym dzieciom", pomijając i w tym przypadku aspekt Kościola wskazany przez Mszał rzymski! 
wezwanie Vaticanum II skierowane do „poszczególnych wiernych i Kościołów partykularnych”: „wspólnymi siłami i sposobami najodpowiedniejszymi... starajmy się - kształtując stale coraz dokładniej życie na Ewangelii - współpracować po bratersku w służbie rodziny ludzkiej, która w Chrystusie Jezusie jest wezwana do rodziny dzieci Bożych" (KDK 92).

\subsection{Famuli-Studzy}

W języku liturgicznym tekstów euchologijnych zgromadzeni na Eucharystię wierni Kościoła i sprawujący misterium paschalne Chrystusa są nazywani: „słudzy” - „famuli”: „użycz sługom Twoim, aby przestrzegali w życiu zobowiązań płynących z sakramentu, który z wiarą przyjęli" zmartwychwstania”22; „pomnażaj w sługach Twoich łaskę, którą ich obdarzyłes”"23; „zwracaj ku sobie serca Twoich sług"24.

Wprowadzenie do tekstów modlitw nowego Mszału określenia "słudzy" stanowi niewątpliwie odwolanie się do osoby Chrystusa, Syna Bożego i Syna Człowieczego, który nie przyszedł, aby mu służono, lecz żeby służyć i dać swoje życie na okup za wielu (Mt 20, 28; Mk 10, 45). Wśród swoich uczniów Jezus jest Tym, który służy (Łk 22, 27), mimo, że jest Panem i Nauczycielem (por. J 13, 12-15).

Św. Paweł, przedstawiając tajemnicę Chrystusa (w wymownym skrócie), głosi w hymnie (Flp 2, 5-11), że „Chrystus wszedł do chwały przyjmując przedtem postać sługi i umierając na krzyżu, by okazać się posłusznym Bogu, swemu Ojcu. (...) Dlatego właśnie imię świętego sługi Bożego, Jezusa, ukrzyżowanego i zmartwychwstałego, jest jedynym źródłem zbawienia"25. Wszyscy chrześcijanie winni stać się naśladowcami swojego Mistrza i Nauczyciela; pasterze winni „mieć przed oczyma przykład Dobrego Pasterza, który przyszedł nie po to, aby Mu służono, lecz aby sam służył" (KK 27); ludzie świeccy

${ }^{21} \mathrm{~K}$ pon. w Oktawie Wielk. (MRP 186). Łacińskie wyrażenie: „concede famulis tuis, ut sacramentum vivendo teneant, quod fide perceperunt", polski Mszał tłumaczy: „spraw, aby Twoi wierni przestrzegali...”.

${ }^{22} \mathrm{~K}$ piątku (=pt.) 2 tyg. wielk. (MRP 198). „Concede nobis, famulis tuis, ut resurrectionis gratiam consequamur", MRP pomijając nazwanie wiernych sługami, tłumaczy: „spraw, abyśmy wiernie Tobie służyli i dostąpili laski zmartwychwstania".

${ }^{23} \mathrm{~K}$ wt. 3 tyg. wielk. (MRP 203). Mszał łaciński podaje wersję: „auge super famulos tuos gratiam quam dedisti"; Mszał dla diecezji polskich tłumaczy: „umocnij w łasce swoich wiernych”, pomijając określenie "słudzy”.

${ }^{24} \mathrm{~K}$ śr. 5 tyg. wielk. (MRP 2180.

${ }^{25} \mathrm{C}$ h. A u g r a i n-M. F. L a c a n, Stuga Boży, [w:] Słownik teologii biblijnej (red. X. Léon-Dufour), Poznań 1985, 808. 
„ze zmiłowania Bożego mają w Chrystusie brata, który choć jest Panem wszystkiego, nie po to przecież przyszedł, aby Mu służono, lecz aby sam służył" (KK 32). Kościół winien zatem kroczyć tą drogą, ,jaką kroczył Chrystus, mianowicie drogą ubóstwa, posłuszeństwa, służby $\mathrm{i}$ ofiary $\mathrm{z}$ siebie aż do śmierci, z której przez zmartwychwstanie swoje powstał Chrystus zwycięzcą. Tak bowiem z nadzieją kroczyli wszyscy Apostołowie, dopełniając wielu udrękami i cierpieniami braki cierpień Chrystusa dla dobra Jego Ciała, którym jest Kościół" (DM 5). Działanie Ducha Świętego sprawia, że chrześcijanie coraz dobitniej uświadamiają sobie własną odpowiedzialność za istnienie i działanie Kościoła oraz są pobudzani „do służenia Chrystusowi i Kościołowi” (DA 1).

Wszyscy chrześcijanie są sługami Jezusa Chrystusa; pierwszymi, przed innymi, są słudzy słowa, ci, co głoszą Ewangelię, wypełniając w ten sposób świętą posługę (por. Rz 15, 16; Kol 1, 23; Flp 2, 22). Poza tym, każdy uczeń Chrystusa, od momentu chrztu przeszedł od „służby” grzechowi i Prawu, „od posługiwania, które było niewolą, na służbę sprawiedliwości i Chrystusa, na służbę, która jest wolnością (J 8, 31-36; Rz 6-7; por. 1 Kor 7, 22; Ef 6, 6)"26. Chrześcijanie wypełniają swoją posługę wobec Boga jak dzieci, a nie jak niewolnicy (por. Ga 4); mogą „pełnić służbę w nowym duchu, a nie według przestarzałej litery” (Rz 7, 6). „Łaska, dzięki której z niewolników stali się przyjaciółmi Chrystusa $(J 15,15)$, pozwala im służyć tak wiernie ich Panu, iż są pewni, że będą uczestniczyć w Jego radości (Mt 25, 14-23; J 15, 10n)"2T.

Termin „słudzy” użyty w euchologii nowego Mszału, podkreśla naszą służbę Bogu, wyrażającą się w prawie i obowiązku składania Najświętszej Ofiary ${ }^{28}$. I Modlitwa Eucharystyczna (=I ME) nazywa uczestników zgromadzenia eucharystycznego „sługami i służebnicami”, których wiara i oddanie są Bogu znane („famulorum famularumque tuarum, (...) quorum tibi fides cognita est et nota devotio"). „Słudzy ołtarza” i cały lud Boży, razem „z Twoim sługą, naszym Papieżem” składają eucharystyczną Ofiarę („cum famulo tuo Papa nostro"); w misterium paschalnym biorą udział „słudzy Boży” oraz lud Boży („nos servi tui, sed et plebs tua sancta”), „wspominając błogosławioną mękę, zmartwychwstanie oraz chwalebne wniebowstąpienie... naszego Pana Jezusa Chrystusa” ( $\mathrm{ME}$ ), składają Bogu „Ofiarę czystą, świętą i doskonałą”. „Sługami i służebnicami” są nazywani także ci, „którzy przed nami odeszli ze znakiem wiary i śpią w pokoju" (I ME). Wszyscy, którzy uczestniczą w Eucharystii, prosząc Boga

${ }^{26}$ Tamże, 890 .

${ }^{27}$ Tamże, 891.

${ }^{28}$ Por. A. D u m a s, Pour mieux comprendre les textes liturgiques du Missel Romain, Not 6(1970)205n. 
o udział w życiu wiecznym i wołając o Jego miłosierdzie, nazywają siebie w obliczu Boga, Jego grzesznymi sługami („Nobis quoque peccatoribus famulis tuis" - I ME).

\section{Wiara zgromadzonego na Eucharystii Kościoła} jest podkreślana stowem: fideles - wierni.

Zachowując wersję starożytnych Sakramentarzy, obecny Mszał rzymski określa słownictwo jakim Kościół zwraca się do Boga: „Przyjmij, Panie, modlitwy wiernych wraz z darami, które składamy”"29; „Wszechmogący Boże, Ty jesteś życiem wiernych”30; „Boże, Ty jednoczysz serca wiernych w dążeniu do Ciebie"31.

Tytuł „wierni” („fideles”) jest charakterystycznym określeniem uczniów Jezusa Chrystusa; tych wszystkich, którzy w Niego wierzą. Wiara jest fundamentalnym warunkiem rzeczywistej przynależności do Chrystusa Pana, obecnego i działającego w eucharystycznej Ofierze; stanowi niezbędny warunek świadomego, czynnego i owocnego uczestnictwa w liturgii (por. KL 11). Wszystkie sakramenty „wiarę nie tylko zakładają, lecz za pomocą słów i rzeczy dają jej wzrost, umacniają ją i wyrażają. Słusznie więc nazywają się sakramentami wiary" (KL 59).

Zgromadzenie liturgiczne jest w istocie tylko wspólnotą tych, którzy wierzą w Chrystusa (por. Dz 10, 43-45; Ef 1, 1; 2 Kor 6, 15). Vaticanum II przypomniał, iż „Zanim ludzie mogą zbliżyć się do liturgii, muszą być wezwani do wiary i nawrócenia: Jakże wzywać będą tego, w kogo nie uwierzyli? Albo jak uwierzą temu, którego nie usłyszeli? I jak będą głosić, jeśliby nie byli posłani? ( $\mathrm{Rz} 10,14 \mathrm{n})$.

Dlatego Kościół niewierzącym głosi orędzie zbawienia, aby wszyscy ludzie poznali jedynego prawdziwego Boga i Jego wysłannika Jezusa Chrystusa... Wierzącym zaś powinien Kościół stale głosić wiarę..." (KL 9).

Wspólnoty wiernych prowadzące życie liturgiczne pod przewodnictwem duszpasterza, skupione zwłaszcza w zbiorowym odprawianiu niedzielnych Mszy świętych, „przedstawiają widzialny Kościół ustanowiony na całej ziemi” (KL 42). Kościół bowiem „ujawnia się przede wszystkim w pełnym i czynnym uczestnictwie całego Ludu Bożego... zwłaszcza w tej samej Eucharystii” (KL 41).

${ }^{29}$ Mnd 7 Niedz. Wielk. (MRP 231). Wersja łacińska brzmi: „Suscipe, Domine, fidelium preces cum oblationibus hostiarum"; w języku polskim natomiast pominięto aspekt wiary uczestników: „Panie, nasz Boże, przyjmij nasze modlitwy i dary, które składamy". Modlitwa ta występuje jeszcze dwukrotnie: wt. 7 tyg. wielk. i 28 Niedz. zwykła.

${ }^{30} \mathrm{~K}$ śr. 4 tyg. wielk. (MRP 211).

${ }^{31} \mathrm{~K}$ pon. 5 tyg. wielk. (MRP 216). 


\subsection{Kościót}

Kościół sprawujący Eucharystię, jest określany w euchologii okresu wielkanocnego także jako: „lud, naród - plebs, populus”.

Słowo „lud”, na określenie Kościoła składającego Najświętszą Ofiarę, jest jednym z częstszych wyrażeń nowego Mszału: „Boże zawsze miłosierny, Ty przez doroczną uroczystość wielkanocną umacniasz wiarę Twojego ludu” ${ }^{2}$; „Panie, nasz Boże, przyjmij dary swojego ludu”,33; "Panie, nasz Boże, przyjmij modlitwy i dary Twojego ludu”34; „Wszechmogący Boże, przyjmij łaskawie dary swojego ludu” ${ }^{\text {; }}$ „Boże, Ty przez wielkanocną ofiarę Chrystusa dałeś swojemu ludowi zbawienie”36; „Boże, Ty w swojej dobroci pomnażasz szeregi wierzącego w Ciebie ludu”, „Boże, nasz Ojcze, wejrzyj łaskawie na lud swój”, „Boże, Ty przywróciłeś młodość ducha swojemu ludowi” ${ }^{39}$; „Boże, nasz Ojcze, przybądź z pomocą swojemu ludowi”" „Boże, Ty dajesz swojemu ludowi udział w laskach odkupienia"41; „Boże... daj swojemu ludowi miłować to, co nakazujesz”42; „Boże... umocnij wiarę i nadzieję swojego ludu” ${ }^{3}$, „Panie, nasz Boże, wejrzyj laskawie na dary Twojego ludu"44.

Określenie „lud” (plebs, populus) używane w tekstach euchologijnych Mszału, oznacza zgromadzenie wiernych zebranych na wspólne sprawowanie Eucharystii. Teksty mszalne potwierdzają wiarę Kościoła wyrażoną przez Sobór m.in. w stwierdzeniu:

${ }^{32} \mathrm{~K} 2$ Niedz. Wielk. (MRP 192).

${ }^{33}$ Mnd 2 Niedz. Wielk. (MRP 192).

${ }^{34}$ Mnd Wigilii Paschalnej (MRP 179).

${ }^{35}$ Mnd pon. w Oktawie Wielk. (MRP 186).

${ }^{36} \mathrm{~K}$ wt. w Oktawie Wielk. (MRP 187).

${ }^{37} \mathrm{~K}$ soboty (=so.) w Oktawie Wielk. (MRP 191).

${ }^{38}$ Mp K so. w Oktawie Wielk. (MRP 191). Nowy Mszał posługuje się tą modlitwą jeszcze sześciokrotnie (!); zob. MRP 194.201.203.209.217. 223.

${ }^{39} \mathrm{~K} 3$ Niedz. Wielk. (MRP 200). „Semper exsultet populus tuus, Deus” w polskim Mszale brzmi: „swoim wiernym”; tekst tej modlitwy występuje jeszcze w $\mathrm{K}$ wt. 6 tyg. wielk. (MRP 224).

${ }_{40} \mathrm{MpK} 5 \mathrm{Niedz}$. Wielk. (MRP 215). Oracja ta występuje jeszcze w siedmiu (!) formularzach nowego Mszału; zob. MRP 196.205.211. 219.225.232.257.

${ }^{41} \mathrm{~K}$ czwartku (=czw.) 6 tyg. wielk. (MRP 227).

${ }^{42} \mathrm{~K}$ pon. 5 tyg. wielk. (MRP 216).

${ }^{43} \mathrm{~K}$ wt. 5 tyg. wielk. (MRP 217). Wersję łacińską: „Deus... da populo tuo fidei speique constantiam” Mszal polski podaje: „umocnij naszą wiarę i nadzieje".

${ }^{44}$ Mnd piątku (=pt.) 7 tyg. wielk. (MRP 236). Wersję Mszału rzymskiego: „Hostias populi tui, quaesumus, Domine, miseratus intende”, Mszał dla diecezji polskich podaje: „Panie, nasz Boże, wejrzyj łaskawie na dary, które Ci składamy". 
„W Mszy, czyli Wieczerzy Pańskiej, lud Boży gromadzi się... aby sprawować pamiątkę Pana, czyli Ofiarę eucharystyczną" (OWMR 7). Eucharystia, ,jako czynność Chrystusa i zorganizowanego hierarchicznie ludu Bożego, stanowi ośrodek całego życia chrześcijańskiego tak Kościoła powszechnego, jak i lokalnego oraz poszczególnych wiernych" (OWMR 1). Chrystus Pan ustanowił eucharystyczną Ofiarę, jako pamiątkę swojej męki i zmartwychwstania, i powierzył ją Ludowi Bożemu nowego Przymierza, Kościołowi (por. KL 47; OWMR 2).

Terminy łacińskie stosowane w euchologii nowego Mszału rzymskiego: „ecclesia, famuli, familia, fideles, plebs, populus” - bardzo wymownie podkreślają aspekt wspólnotowy sprawowanej Eucharystii. Ofiara Eucharystyczna jest składana przez cały Lud Boży, Kościół, zgodnie zresztą z Boskim sposobem realizacji zbawienia. Vaticanum II wyraźnie o tym poucza, twierdząc iż podobało się „Bogu uświęcać i zbawiać ludzi nie pojedynczo, z wykluczeniem wszelkiej wzajemnej między nimi więzi, lecz uczynić z nich lud, który by Go poznawał w prawdzie i zbożnie Mu służył. Przeto wybrał sobie Bóg na lud naród izraelski, z którym zawarł przymierze i który stopniowo pouczał, siebie i zamiary woli swojej objawiając w jego dziejach i uświęcając go dla siebie. Wszystko to jednak wydarzyło się jako przygotowanie i jako typ owego przymierza nowego i doskonałego, które miało być zawarte w Chrystusie... Chrystus ustanowił to nowe przymierze, a mianowicie nowy testament we krwi swojej (por. 1 Kor 11, 25), powołując spośród Żydów i pogan lud, który nie wedle ciała, lecz dzięki Duchowi zróść się miał w jedno i być nowym Ludem Bożym. Albowiem wierzący w Chrystusa, odrodzeni (...) z wody i Ducha Świętego (por. J 3, 5n), ustanawiani są w końcu „rodzajem wybranym, królewskim kapłaństwem, narodem świętym, ludem nabytym..., co niegdyś nie był ludem, teraz zaś jest ludem Bożym" (1 P 2, 9n)" (KK 9).

Euchologia nowego Mszału potwierdza naukę Soboru, iż „Kościół Chrystusowy jest prawdziwie obecny we wszystkich prawowitych miejscowych zrzeszeniach wiernych, które trwając przy swoich pasterzach same również nazywane są Kościołami w Nowym Testamencie (por. $\mathrm{Dz} 8,1 ; 14,22 ; 20,17$ ). Są one bowiem na swoim miejscu nowym Ludem powołanym przez Boga w Duchu Świętym i w pełności wielkiej (por. 1 Tes 1, 5). W nich głoszenie Ewangelii Chrystusowej zgromadza wiernych i w nich sprawowana jest tajemnica Wieczerzy Pańskiej, „aby przez ciało i krew Pana zespalali się z sobą ściśle wszyscy bracia wspólnoty” (KK 26).

Eucharystyczna Ofiara - pamiątka Męki i Zmartwychwstania Chrystusa, powierzona umiłowanej Oblubienicy Kościołowi - jest Ofiarą Kościoła, który „nieustannie odnawia to misterium” (OWMR 
55d). Kościół Chrystusowy, który nigdy nie zaprzestał zbierać się na odprawianie paschalnego misterium, sprawując Eucharystię, w której uobecnia się zwycięstwo i triumf śmierci Chrystusa (por. KL 6) Eucharystią „ustawicznie żywi się i wzrasta” (KK 26).

Teksty euchologijne okresu wielkanocnego stanowią wymowne świadectwo wiary Kościoła, iż powierzona mu przez Chrystusa Ofiara eucharystyczna jest sprawowana przez cały Lud Boży. „Celebrowanie eucharystyczne, które dokonuje się we Mszy świętej, jest czynnością nie tylko Chrystusa, ale i Kościoła. (...) Kościół zaś, oblubienica i służebnica Chrystusa, wypełniając razem z Nim rolę kapłana i żertwy ofiaruje Go Ojcu, a jednocześnie siebie samego całego ofiaruje z Nim. W ten sposób Kościół, (...) razem z Chrystusem składa Ojcu w Duchu Świętym dziękczynienie za wszystkie dobra, których udziela On ludziom w akcie stworzenia i w sposób oczywisty $\mathrm{w}$ tajemnicy paschalnej, oraz uprasza Ojca o przyjście Jego Królestwa" (EM 3 c).

\section{EKLEZJALNY WYMIAR PASCHY: JEDNOŚĆ LUDU BOŻEGO}

Przedwieczny Ojciec postanowił wierzących w Chrystusa zgromadzić w Kościele świętym, „który już od początku świata ukazany przez typy, cudownie przygotowany w historii narodu izraelskiego i w Starym Przymierzu, ustanowiony w czasach ostatecznych, objawiony został przez wylanie Ducha, a w końcu wieków osiągnie swe chwalebne dopełnienie" (KK 2).

Jezus Chrystus przez śmierć i zmartwychwstanie swoje, odkupił człowieka, przemienił w nowe stworzenie (por. Ga 6, 15; 2 Kor 5, 17) i „braci swoich powołanych ze wszystkich narodów, ustanowił w sposób mistyczny jako ciało swoje" (KK 7).

Sobór Watykański II poucza, iż życie Chrystusowe „rozlewa się na wierzących" w Kościele, wtedy, gdy przez sakramenty wierni jednoczą się, w sposób rzeczywisty, „z umęczonym i uwielbionym Chrystusem", a więc przez udział w tajemnicy paschalnej Chrystusa (por. KK 7). Wspólnota z Chrystusem i nawzajem ze sobą urzeczywistnia się w sposób szczególny „przy łamaniu chleba eucharystycznego"; ponieważ jeden jest chleb, przeto my, liczni, tworzymy jedno Ciało. Wszyscy bowiem bierzemy z tego samego chleba (1 Kor 10, 17).

Chrystus Pan, „zanim ofiarował sam siebie na ołtarzu krzyża jako niepokalaną hostię", nie tylko modlił się do Ojca za wierzących „aby wszyscy byli jedno" (J 17, 21), ale „w swoim Kościele ustanowił przedziwny Sakrament Eucharystii, który oznacza i sprawia jedność Kościoła” (DE 2). 
W celebracji eucharystycznej Kościół wyznaje swoją wiarę w jednoczące działanie Boga w Jezusie Chrystusie, mocą Ducha; Eucharystia jest nie tylko wspomnieniem (anamnesis) zbawczych dzieł Boga dokonanych w przeszłości, ale znakiem i gwarancją ustawicznego działania Boga w sercach ludzi ${ }^{45}$. Teksty euchologijne Mszału okresu paschalnego potwierdzają to lex credendi Kościoła: „Boże, Ty zjednoczyłeś różne narody w wyznawaniu Twojego imienia, spraw, aby wszyscy ochrzczeni zachowali jedność wiary w sercach i miłość w uczynkach" ${ }^{46}$; „....Boże (...) spraw, aby rozproszone narody i podzielone odmiennością języków... zjednoczyły się w wyznawaniu Twojego imienia" 47 ; "Boże, Ty przez misterium dnia dzisiejszego uświęcasz swój Kościół ogarniający wszystkie ludy i narody”48, „Boże, Ty jednoczysz serca wiernych w dążeniu do Ciebie" ${ }^{49}$.

Mocą Ducha Świętego obecnego w misterium Kościoła i Eucharystii urzeczywistnia się jedność wierzących; Eucharystia jest znakiem jedności i wspólnoty, którą gromadzi Duch Święty oraz ustawicznym wezwaniem do zjednoczenia. Taką wiarę wyraża modlitwa nowego Mszału: „Miłosierny Boże, spraw, aby Twój Kościół zgromadzony przez Ducha Świętego... szczerze się starał trwać w jedności”ó.

Duch Święty został zesłany na wszystkich, którzy stali się przybranymi dziećmi i zjednoczył ich z Jednorodzonym Synem Bożym; Duch Święty „zjednoczył różne języki w wyznawaniu tej samej wiary"s1.

Działanie Ducha Świętego stanowi bardzo ważny moment Paschy Chrystusa gwarantując zbawczą skuteczność misterium paschalnego $\mathrm{w}$ stosunku do ludzi. Owocem tego działania jest zjednoczenie wiernych z Ojcem i Synem, a także jedność wszystkich wierzących w wyznawaniu tej samej wiary. „Liturgia ukazuje w niezrównany sposób trynitarny charakter zbawczego działania

${ }^{45}$ Por. W. H r y n i e w i c z, Sakrament Paschy i Pięćdziesiątnicy. Tajemnica Eucharystii w świetle dialogu katolicko-prawosławnego [w:] Eucharystia i posłannictwo, (pr. zb. pod red. L. Górki i W. Hryniewicza), Warszawa 1987, 32 .

${ }^{46} \mathrm{~K}$ czw. w Oktawie Wielk. (MRP 189).

${ }^{47}$ K Niedz. Zesł. Ducha Św. (Msza wigilijna) (MRP 238). Mszał polski, łacińską wersję: „praesta, ut, gentium facta dispersione, divisiones linguarum ad unam confessionem tui nominis... congregentur" przetlumaczyl: „niech Duch Święty zjednoczy rozdzielone narody, aby każdy w swoim języku oddawal Ci chwalę".

${ }^{48}$ K Niedz. Zesł. Ducha Św. (Msza w dzień) (MRP 239).

${ }^{49} \mathrm{~K}$ pon. 5 tyg. wielk. (MRP 216).

${ }^{50} \mathrm{~K}$ śr. 7 tyg. wielk. (MRP 234).

${ }^{51}$ Prefacja o Zesł. Ducha Św. (Zesłanie Ducha Świętego dopelnieniem dziela zbawienia) (MRP $44^{*}$ ). 
Boga w świecie. Sprawując Eucharystię, Kościół sławi Boga Ojca i dziękuje mu za zbawienie, które stało się udziałem ludzi w Chrystusie i które uobecnia się w każdej celebracji mocą Ducha Świętego. Wszystkie modlitwy eucharystyczne (anafory) posiadają dlatego - zgodnie z najstarszą tradycją - ten właśnie trynitarny charakter. Od sławienia Ojca przechodzą do dziękczynienia za zbawcze dzieło Syna, a następnie błagają Ducha Świętego, aby zstąpił na wspólnotę wierzących oraz na dary eucharystyczne, a w ten sposób uobecnił paschalną ofiarę Chrystusa i zjednoczył wszystkich w jedno ciało swoją mocą" ${ }^{2}$. Dzięki Duchowi Swiętemu misterium paschalne trwa w Kościele; działanie Ducha Świętego zapewnia jedność i rozwój Kościoła jako wspólnoty. Duch Święty udzielił wszystkim narodom daru poznania Boga, a przez różnorodność charyzmatów zapewnia jedność wierzących w Chrystusa. „Duch Święty, który mieszka w wierzących i napełnia cały Kościół oraz nim kieruje, jest sprawcą tej... wspólnoty wiernych i tak dogłębnie wszystkich zespala w Chrystusie, iż jest zasadą jedności Kościoła" (DE 2). Jezus Chrystus przez Ducha Świętego sprawia, że społeczność Jego Kościoła ,jednoczy się coraz doskonalej w wyznawaniu jednej wiary, we wspólnym spełnianiu kultu Bożego oraz w braterskiej zgodzie rodziny Bożej” (DE 2).

Eucharystia tworzy wspólnotę życia z Chrystusem oraz wzajemną więź jedności między ludźmi; w Eucharystii uobecnia się zwycięstwo i triumf śmierci Chrystusa. Dokonuje się to w Kościele, będącym „sakramentem jedności”: Kościół bowiem „to lud święty zjednoczony i zorganizowany pod zwierzchnictwem biskupów" (KL 26).

Euchologia okresu wielkanocnego potwierdza słuszność wezwania Soboru Watykańskiego II, ażeby „wszyscy chrześcijanie skupili się w jednym sprawowaniu Eucharystii w jedność jednego i jedynego Kościoła, której Chrystus od początku użyczył swemu Kościołowi; wierzymy, że ta jedność trwa nieutracalnie w Kościele katolickim i ufamy, że z dniem każdym wzrasta aż do skończenia wieków" (DE 4).

Kraków

Ks. JAN JANICKI

${ }^{52}$ W. H r y n i e w i c z, Sakrament Paschy $i$ Pięćdziesiątnicy... art. cyt., 34 n. 